\title{
TECHNOLOGICAL PROCESS OF SEWAGE SLUDGE DE-WATERING BY IMPULSE METHOD AND ASSESMENT OF OPTIONS TO USE DRIED MATERIAL
}

\author{
Dagnija Lazdina $^{1}$, Andis Lazdins ${ }^{1}$, Ieva Bebre ${ }^{1}$, Igors Gusarevs ${ }^{1,2}$ \\ ${ }^{1}$ Latvian State Forest Research Institute "Silava"; ${ }^{2}$ LTD Orvi, Latvia \\ dagnija.lazdina@silava.lv, orvi@inbox.lv
}

\begin{abstract}
Waste water sewage sludge is one of municipal waste materials that could be used for nutrient recycling in agriculture, plantation forestry or re-cultivated areas. Sewage sludge contains at least $80 \%$ of water and nutrient rich organic materials what could be used for fertilization of bare soils or for energy production instead of landing on landfills. The de-watering process of sludge by using the impulse method has less energy consumption and higher content of dry matter in the final product is reached in comparison with traditional drying. The aim of the study is to elaborate a method for sewage sludge drying, which allows saving the biological value of final organic material. Impulse interval, frequency, air pressure and temperature in the camera are the key factors for an economically effective process and reaching of qualitative final product. The product could be used for fertilization of non-food products, tree planting, perennial grasses for seed production etc. If sludge contains too high concentration of heavy metals, it could be burned for energy production, and just ashes deponent on landfills. The technological and energy consumption aspects of the methods were analyzed. For sewage sludge containing a low content of heavy metals. Drying is more sustainable after - and pretreatment methods before recycling of plant nutrient elements included in sludge organic material for farming. Transport of dried material is more economical as fresh mass, as well dry material does not smell. The barriers for implementation of these technologies into common practice are more political than technical.
\end{abstract}

Keywords: waste water sewage sludge, pneumatic pulse method.

\section{Introduction}

Sewage sludge is one of municipal waste materials that could be used for nutrient recycling in agriculture, plantation forestry or re-cultivated areas. Sewage sludge contains at least $80 \%$ of water and nutrient rich organic materials what could be used for fertilization of bare soils or for energy production instead of landing on landfills [1].

Three methods are mainly applied: convective drying, conductive drying and solar drying, each one presenting different characteristics [1]. Thermal drying with the use of a pneumatic pulse method significantly speeds up the drying process of bulk materials $[1 ; 2]$ and sludge is one of such materials. By using the impulse method less input of energy to the de-watering process of sludge and higher content of dry matter in the final product could be reached. Thermal drying of sewage sludge is not cost effective if heat is supplied from primary energy sources, but can be effective if waste heat obtained during the drying process is used. Appropriate integration can be realized between wastewater treatment plants and power plants operating on production waste, by recycling waste as an energy carrier for drying sewage sludge [3]. The developed quadratic models show that the optimisation of the dosage of air conditioners allows to increase dehydration by $70 \%$, thereby reducing $50 \%$ and $54 \%$ emission of odours and volatile sulphur compounds. The optimisation of the conditioning process was experimentally tested [1].

For sustainable management of municipal sewage sludge not only available technologies should be taken into account, but also other parameters, such as policy regulations and socio-economic issues. Some authors think that drying is too simple solution and the next generation technologies should be used, for example, pyrolysis seems to be the optimal thermochemical treatment option compared to incineration and gasification. Pyrolysis of a deposit of sewage favors to energy saving, restoration of materials and production of high-grade materials, providing the decision "without a wastage". Pyrolysis of ooze is an innovative process, which can transform both the crude and digested ooze to useful bioenergy in the form of naphtha and gas, forming biochar as by-product, which is ecologically steady and has the capacity for binding of carbon and conditioning of the soil, and also for the absorptive production [4].

Successful seeding and planting efforts on degraded sites, after fertilization and soil cultivation are reasons to believe that natural seeding can supplement or even replace artificial stand establishment $[1 ; 5]$. Organic residues contain plant nutrient elements and after adequate treatment are suitable for using as fertilizers [6]. 


\section{Materials and methods}

The paper introduces with the method for sewage sludge drying, which allows to save the biological value of the final organic material. The authors have the hypothesis that the impulse interval, frequency, air pressure and temperature in the camera are the key factors for an economically effective process and reaching of qualitative final product with valuable less water content as after ordinary dewatering methods, what significantly increases the effectiveness of future re-use of organic materials.

The experimental drying module was designed and manufactured for definition and check of effectiveness of the key parameters of hot drying of a deposit of waste water sludge or other organic materials with high water content, the effectiveness of the process was speeded up with application of the pneumatic pulse method [2]. The parameters of the main parts of the experimental drying module were chosen after determining the mass of the dried sample required for the experiment, and also for performing preliminary calculations (BlowerType - AAVA 400/P T2; Power $-N=0.55 \mathrm{~kW}$; Amount of airflow $-Q=200 \mathrm{~m}^{3} \cdot \mathrm{h}^{-1}$; Pressure $-P=2650 \mathrm{~Pa}$; Diameter of the outlet of the air channel $-d=54$ mm.; Electric heat generator; Power, max. $-N=2.4 \mathrm{~kW}$; Amount of airflow $-Q=140 \mathrm{~m}^{3} \cdot \mathrm{h}^{-1}$; Temperature regimes $-T 1=50{ }^{\circ} \mathrm{C}, \quad \mathrm{T} 2=100{ }^{\circ} \mathrm{C}$; Diameter of the air channel $D=160 \mathrm{~mm}$ ).

The blower is connected to the heat generator by means of a cone with an angle of $10^{\circ}$. The operating temperature mode was defined as $T 1=50^{\circ} \mathrm{C}$. The drive of the pulsator is made with the help of a gear motor HU 40S 72K4, 122 revolutions per minute. The impulse provides 4 pulses per second. The scheme of the experimental drying module is shown in Figure 1.

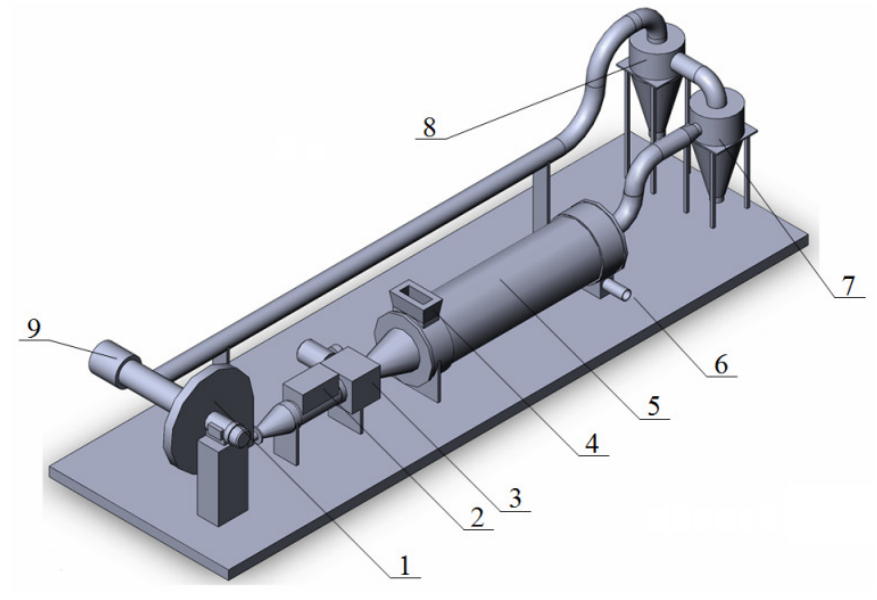

Fig. 1. Scheme and design of the experimental drying module.: 1 - blower; 2 - electric heat generator; 3 - pulsator; 4 - loading hatch; 5 - drying chamber; 6 - unloading hatch; 7 - cyclone; 8 -hydraulic cyclone; 9 - air valve

The blower supplies air to the heat generator. Passing through the heat generator, the air is heated and then enters the pulsator. The pulsator is a hollow cylinder rotating in a closed housing. The perimeter of the cylinder is divided into four equal sectors. Two, diametrically opposite, sectors are open and air passes freely through them. Rotating, the pulsator sectors periodically open and close the air outlet channel in the body, thereby producing regular interruptions in the flow of air - impulses. Two pulses are formed per turn of the pulsator axis. The pulsator supplies heated air to the drying chamber with temporary breaks, pulses. In the drying chamber, the air stream "pushes out" the water molecules from the dried material with pulses and takes them out of the drying chamber. The structure and dimensions of the rectangular drying chamber were determined based on the characteristics of the air flow and access to the dried sample [2].

The structure and dimensions of the rectangular drying chamber (Figure 2) were determined based on the characteristics of the airflow and taking into account access to the dried sample.

In the previous experiment [1], the effect of pulsed air flow on the process of drying sewage sludge was tested: temperature regimes during the drying of sewage sludge using the pneumatic pulse method; angle of incidence of air flow to the material during the drying of sewage sludge using a 
pneumatic pulse method. The study was carried out in a stationary rectangular drying chamber and in a rotating cylindrical drying chamber. The angle of incidence of the air flow to the dried sample was determined at $30^{\circ}$ and $45^{\circ}$. Then, after making structural changes, the airflow to the drying chamber was fed from the bottom. The rotating cylindrical drying chamber (Figure 2) was applied taking into account the fact that the drying chamber, taken as a prototype of the industrial equipment for drying and burning sludge, has the same cylindrical shape. The dimensions of the rotating cylindrical drying chamber were determined based on the characteristics of the air flow. The air stream may be fed in parallel with the dried sample in the cylinder or, alternatively, directed to the dried sample.

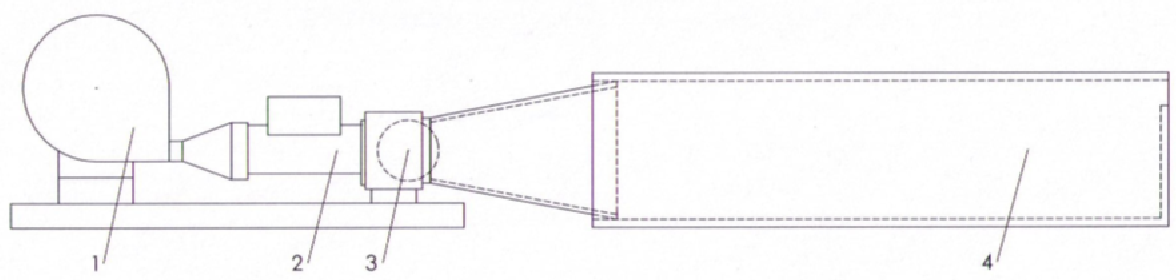

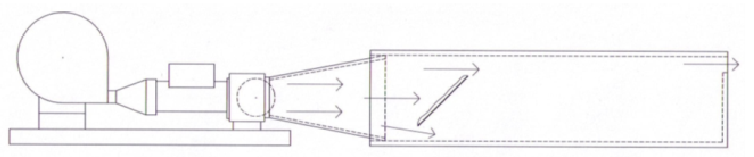

on the material

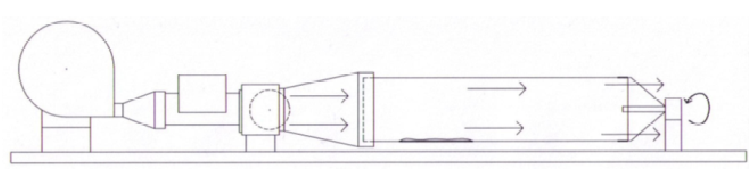

parallel to the material

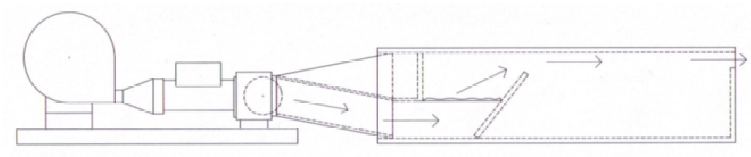

from the bottom

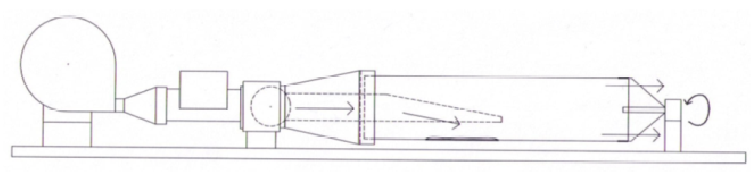

on the material

Fig. 2. Airflow tested in the experimental drying module: 1 - blower; 2 - electric heat generator; 3 - pulsator; 4 - drying chamber

\section{Results and discussion}

Calculation of inputs and benefits by using the method of drying wet organic material with impulses shown in Table1 are very promising in terms of energy efficiency of the process.

Benefits from dewatering of waste water sludge ( 2 milj capita)

\begin{tabular}{|c|c|c|c|c|}
\hline Parameter & Unit & $\begin{array}{c}\text { Without } \\
\text { impulse }\end{array}$ & $\begin{array}{c}\text { With } \\
\text { impulse }\end{array}$ & Difference \\
\hline Productivity of the process & $\begin{array}{c}\mathrm{m}^{3} \mathrm{per} \\
\text { day }\end{array}$ & 8 & 8 & 0 \\
\hline $\begin{array}{c}\text { Content of water in sludge before } \\
\text { treatment }\end{array}$ & $\mathrm{g} \cdot \mathrm{kg}^{-1}$ & 860 & 860 & 0 \\
\hline $\begin{array}{c}\text { Content of water in sludge after } \\
\text { treatment }\end{array}$ & $\mathrm{g} \cdot \mathrm{kg}^{-1}$ & 300 & 300 & \\
\hline Energy consumption & $\begin{array}{c}\mathrm{kWl}^{-1} \\
\mathrm{H}_{2} \mathrm{O}\end{array}$ & 0.07 & 0.04 & $\begin{array}{c}-0.03 \\
(42 \%)\end{array}$ \\
\hline
\end{tabular}

It has been found that by optimizing the energy consumption of the aerobic composting process using heat allocated to solve the second important waste management problem, such as wastewater treatment. Energy and mass balances are presented in the preliminary feasibility study. With regard to a composting plant with a capacity of $15,000 \mathrm{t} \cdot \mathrm{y}^{-1}$ of food waste, an estimate of the power obtained from the regenerated heat for the entire livestock resulted in $42 \mathrm{~kW}$ [7].

Communal waste water sludge produced in Latvia is a high quality material, the main economical limiting factor for implementation of recirculation of waste water sludge is too low dry mater content 
in biomass what could be reduced after drying of sludge [8]. The impulse method could be considered as economically reasonable solution for cities with no more than 2000000 citizens. Other authors are also highlighting the importance of dewatering of waste water sludge as a solution for more effective reuse of such kind organic material as fertilizer or for incineration and heat production [7;9].

The results of re-cultivation of former peat mining areas show that waste water sludge in long term is a better substance for compensation of lacking elements as well as organic compounds and it significantly promotes ingrown and the yield of cut - over peat land afforestation with birch, black alder and pine than a proportional amount of minerals with approximately the same macroelement concentration applied in Figure 3.

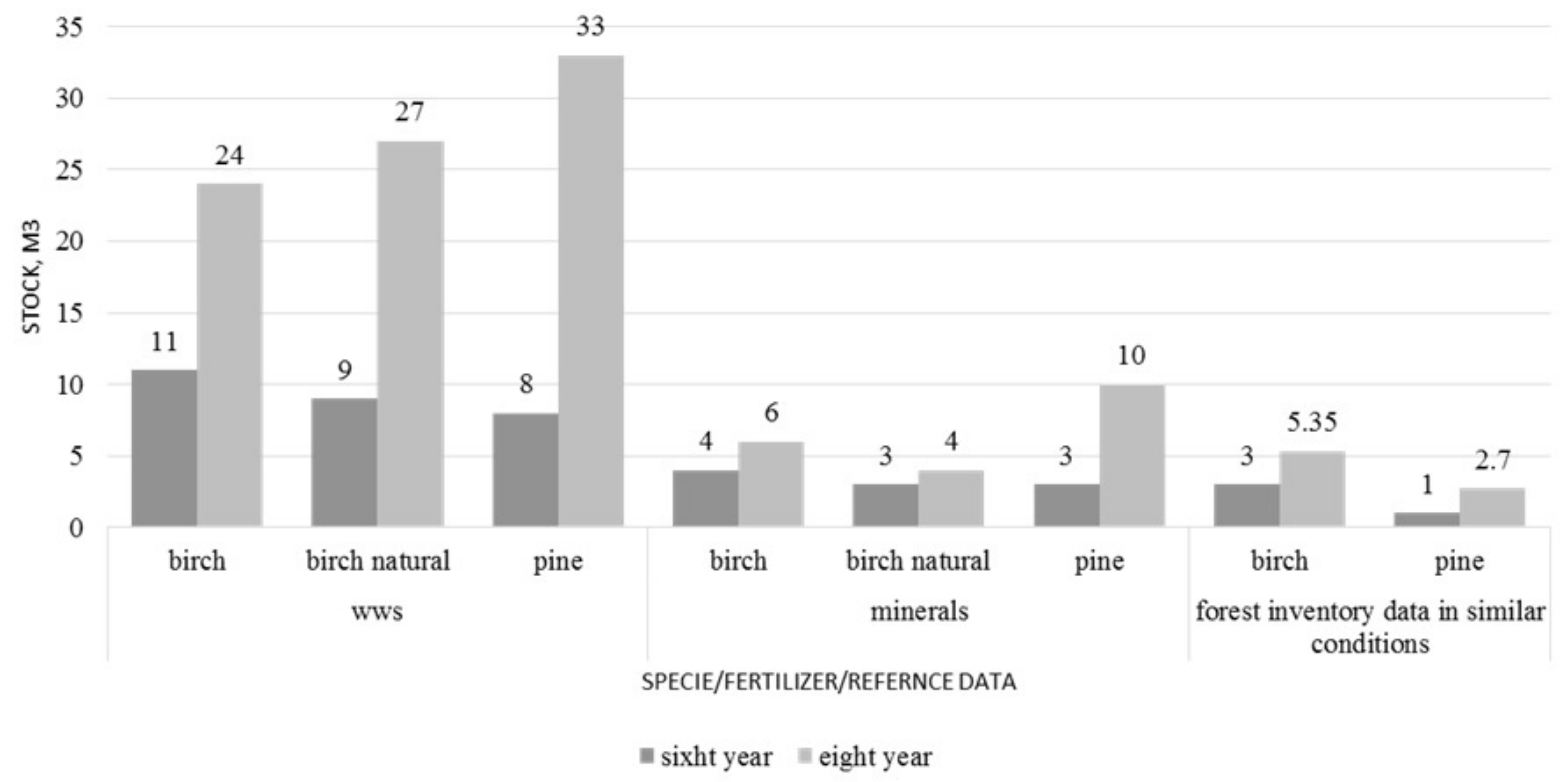

Fig. 3. Yield of planted and naturally ingrown trees (at age of six and eight years) in comparison with the forest statistical inventory measurement data (WWS - waste water sludge)

The facts that drying decreases the mass and volume of the treated waste water sludge and increases the concentration of phosphorus in the final product and decreases $\mathrm{pH}$ of the product were already found in the previous study of the authors [10] and other scientists describe the importance of macroelements and nitrogen $[5 ; 11 ; 12]$. Dried waste water could be even a more effective fertilizer, to promote microflora and fauna development [13] and a source or micronutrients often lacking in soils $[1 ; 12]$. The product could be used for fertilization of non-food products, tree planting, perennial grasses for seed production $[5 ; 14]$. Transport of dried material is more economical as fresh mass; as well as dry material does not smell.

\section{Conclusions}

1. The method for effective dewatering of waste water sludge - drying with the impulse method consumed $42 \%$ less energy than simple drying.

2. Dewatered waste water sludge has high potential to be used for recultivation of dergraded areas. After recultivation of former mining areas with waste water sludge fertilizers eight year old pine and birch trees have higher yield as on similar soils in natural conditions.

3. Drying of high quality waste water sludge should be promoted for use as fertilizer for degraded areas and for cultivation of non-food products.

\section{References}

1. Gusarevs I. Prospects of a pneumatic pulse method of dehydration of the sewage sludge. In: Annual 20th International Scientific Conference Proceedings „Research for Rural Development 2014" Volume No. 2, 2014,Latvia University of Agriculture, Jelgava, Latvia, pp. 161-163. 
2. Gusarevs I. Advantages of the pneumatic pulse method for dehydration of the sewage sludge. In: Annual 19th International Scientific Conference Proceedings ,Research for Rural Development 2013” Volume No. 2, 2013, Latvia University of Agriculture, Jelgava, Latvia, pp. 148-152.

3. Bianchini A., Bonfiglioli L., Pellegrini M., Saccani C. Sewage sludge drying process integration with a waste-to-energy power plant. Waste Management vol.42, 2015, pp. 159-165.

4. Samolada M.C., Zabaniotou A.A. Comparative assessment of municipal sewage sludge incineration, gasification and pyrolysis for a sustainable sludge-to-energy management in Greece. Waste Management, vol.34, 2014, pp. 411-420.

5. Lazdina D. Using of wastewater sewage sludge in short rotation willow coppice. Summary of thesis Notekūdeņudūņuizmantošanasiespējaskārkluplantācijās in Latvian), Jelgava, 2009 p. 58. [online] [accessed on 01.03.2016.]. Available: http://llufb.llu.lv/dissertation-summary/forest/ Dagnija_Lazdina_promocijas-darba-kopsavilkums-2009-LLU-MF.pdf

6. Rancane S., Karklins A., Lazdina D., Berzins P.Biomass yield and chemical composition of perennial grasses for energy production. Contents of Proceedings of 14th International Scientific Conference Engineering For Rural Development, May 20-22, pp. 546-551.

7. Rada E.C., Ragazzi M., Villotti S., Torretta V. Sewage sludge drying by energy recovery from OFMSW composting: Preliminary feasibility evaluation. Waste Management, vol. 34, 2014, pp. 859-866.

8. Apsekojums Sadzīves notekūdeņu dūņu kvalitāte Latvijas ūdenssaimniecībās, to apstrādes un izmantošanas plānošanas priekšlikumui zstrāde. (Survey of waste water sludge qualitative parameters) Biedrības "Latvijas Biotehnologijas asociācija" (LB A) struktūrvienība CLEANTECH LATVIA Ar LVAF noslēgtā līguma numurs: 1 20/229 29.10.2014 Rīgā, 2015. gada 30.janvārī Online [3.03.2016.] Available at:

http://lvafa.gov.lv/materiali/images/faili/projektu_materiali/petijumi/2014/Apsekojums \%20LVAF \%20Cleantech \%20Latvia \%202014.pdf

9. Cai L., Chen T.B., Gao D., Guo-Di Zheng G.D., Liu H..T., PanT.H. Influence of forced air volume on water evaporation during sewage sludge bio-drying. Water Research vol. 47, 2013, pp. 4767-4773.

10. Gusarevs I., Lazdina D. Alternative treatments for utilization of dehydrated sewage WASTE water sludge. Civil Engineering ' 15 5th International Scientific Conference Proceedings, Vol. 5 Jelgava, Latvia University of Agriculture, 2015 pp 151-155.

11. Ferreiro-Domínguez N., Nair V. D., Freese D. Phosphorous dynamics in poplar silvopastoral systems fertilised with sewage sludge. Agriculture, Ecosystems and Environment vol. 223, 2016, pp. 87-98.

12. Pesonen J., Kuokkanen V., Kuokkanen T., Illikainen M. Co-granulation of bio-ash with sewage sludge and lime for fertilizer use. Journal of Environmental Chemical Engineering, 2015 (in press).

13. Andrés P., Mateos E., Tarrasón D., Cabrera C., Figuerola B. Effects of digested, composted, and thermally dried sewage sludge on soil microbiota and mesofauna. Applied Soil Ecologyvol. 48, 2011, pp. 236-242.

14. Ferreiro-Domínguez N., Rigueiro-Rodríguez A., Mosquera-Losada M.R. Sewage sludge fertiliser use: Implications for soil and plant copper evolution in forest and agronomic soils. Science of the Total Environment vol. 424, 2012, pp. 39-47. 